\title{
Congeneric variation in surfgrasses and ocean conditions influence macroinvertebrate community structure
}

\author{
Orissa M. Moulton ${ }^{1,2, *}$, Sally D. Hacker ${ }^{1}$ \\ ${ }^{1}$ Department of Zoology, Oregon State University, Corvallis, Oregon 97331, USA \\ ${ }^{2}$ Present address: Department of Ecology and Evolution, University of Chicago, Chicago, Illinois 60637, USA
}

\begin{abstract}
Foundation species are important components of ecosystems because they provide habitat and ameliorate stressful conditions for residents. Comparisons of congeneric foundation species have mostly been limited to comparisons of native and invasive species, with less attention paid to multiple native species. Surfgrasses (Phyllospadix spp.) are ubiquitous foundation species on the coast of Oregon, USA, protecting resident invertebrates from waves and providing them with access to sandy substrate in an otherwise rocky habitat. Two native surfgrass species, $P$. scouleri and $P$. serrulatus, have superficially similar morphological characteristics and co-occur within the same rocky intertidal zones. We investigated whether these native congeneric species function similarly as foundation species by comparing the 2 species' morphology, sediment accretion and associated resident macroinvertebrates at 3 capes that vary in oceanographic conditions. The results show that although the macroinvertebrate abundance was the same between surfgrass species, macroinvertebrate species richness, composition and functional groups varied considerably, with more infauna and deposit feeders found within P. serrulatus. P. serrulatus also had fewer tillers and rhizomes, and lower biomass per given area, but greater sediment accretion than its congener $P$. scouleri. One notably strong result was the difference in macroinvertebrate abundance among capes, with Cape Perpetua having 2.5-3 times more animals per given area than Capes Foulweather or Blanco. Overall, we conclude that although the 2 co-occurring surfgrass congeners provided functionally different habitat for resident macroinvertebrates, regional oceanographic processes (i.e. upwelling and productivity) may be more influential in determining the overall abundance and productivity of these diverse animal communities.
\end{abstract}

KEY WORDS: Phyllospadix · Surfgrass · Congeners · Foundation species · Macroinvertebrate community $\cdot$ Ocean upwelling $\cdot$ Oregon

\section{INTRODUCTION}

Large and structurally complex organisms can provide important ecosystem functions for associated resident species, including refuge from predation or amelioration of physically demanding conditions, thus enhancing diversity and abundance (Bertness \& Callaway 1994, Hacker \& Gaines 1997, Stachowicz 2001, Bruno et al. 2003). Trees, grasses, corals and seaweeds are classic examples of species that function in this way, and are often termed foundation or dominant species because of their ability to provide structural and physical definition to entire ecosystems (Dayton 1971, Hay et al. 2004). Foundation or dominant species have large effects on the community by virtue of their high abundance or biomass (Power et al. 1996). In many cases, foundation species have community-wide effects via direct and indirect means (see Table 8.2 in Bruno \& Bertness 2001 for examples) and they can be strong competitors or facilitators of space, nutrients or light depending on the mediated physical conditions (e.g. Bertness \& Hacker 1994, Bertness et al. 1999).

In traditional ecological literature, foundation species are typically viewed in a general way with little consideration of their specific functional roles for associated species. Jones et al. (1994) used the concept of 'ecosystem engineers' to exemplify how these foundation species can modify their physical environment. Despite the recent increase in research on ecosystem engineers and the functional role of foundation species, 
questions remain about foundation species, especially those that are closely related taxonomically. For example, are their roles general and thus highly redundant, or does each have specific functions that make them particularly unique? Given the important role these species play in maintaining species diversity (Hacker \& Gaines 1997, Bruno et al. 2003), understanding the variability between different foundation species has important conservation and management implications.

Investigations concerning the functional roles of closely related foundation species have primarily focused on comparisons between native and nonnative congeners. For example, 2 species of eelgrass, Zostera marina (native in temperate regions of the Pacific and Atlantic basins) and Zostera japonica (native between northeastern Russia and tropical Vietnam), currently co-occur on the Pacific Northwest coast of North America, a region where $Z$. marina has evolved in the absence of $Z$. japonica (Bando 2006, Ruesink et al. 2010). Studies on their co-occurrence have shown that $Z$. japonica can alter several components of the estuaries they invade, e.g. nutrient dynamics (Hahn 2003, Larned 2003) and benthic community structure (Posey 1988). Structural differences between these congeners, e.g. canopy density, height and blade width (Ruesink et al. 2010), result in variation in the retention of planktonic larvae and the overall quality of nursery and feeding habitat for commercially important marine species (Jenkins \& Sutherland 1997, Webster et al. 1998). Interspecific competition between Zostera spp. congeners can also lead to habitat-altering structural changes, including reductions in aboveground $Z$. marina biomass, potentially altering its effectiveness as a foundation species (Ruesink et al. 2010). This example and many others in the invasive species literature (e.g. Trowbridge 1995, Hacker et al. 2011) suggest that foundation species with similar phylogeny, habitat and morphology may have very different functional consequences for associated species. Surprisingly, although the invasive species literature is rich with such native/ non-native congener examples, similar studies comparing native congeners are rare (but see Ellison et al. 2005). Even less common are examples that consider the role of physical context (e.g. nutrients, sedimentation, wave action and precipitation) on how native congeners function, which has been shown to be important for some foundation species (e.g. Hacker \& Dethier 2006, 2009, Hacker et al. 2011).

In this study, we focus on the functional role of native seagrass congeners, surfgrasses in the genus Phyllospadix spp., as habitat for a diverse and understudied macroinvertebrate community along the Oregon coast, USA. Generally, seagrasses serve many important estuarine and coastal functions, including habitat and food for invertebrates and fishes, attenuation of waves and stabilization of sediments, and nutrient and carbon uptake (Barbier et al. 2011). As a result, faunal diversity and abundance are often higher within seagrass meadows than in adjacent unvegetated areas, particularly sandy substrate (Hemminga \& Duarte 2000). However, the functional role of surfgrasses as habitat has been poorly studied (but see Stewart \& Myers 1980, Turner \& Lucas 1985), despite the observation that they occupy more space than any other single species in the Oregon lower rocky intertidal zone (Turner 1985, Menge et al. 2005). Surfgrasses have several adaptations to withstand heavy surf, including extensive rootlet development, rhizomes with a thick-walled outer cortical layer, production of adhesive material for binding to rocky substratum and basal meristematic tissue in their leaves (Gibbs 1902, Dennis \& Halse 2008). Once established, they accrete sediment from the water column, creating 'sandy beach islands' (Crouch 1991) and thus playing a role in stabilization of rocky substratum against wave surge and erosion (Gibbs 1902). Surfgrasses flourish in relatively high-energy environments (Fishlyn \& Phillips 1980), and thus provide an important protective habitat for small macroinvertebrates that might otherwise be excluded from these turbulent, high-energy conditions.

Three species of surfgrass occur along the Pacific Northwest coast of the USA: Phyllospadix serrulatus Rupr. ex Ascher., P. scouleri Hook., and P. torreyi Wats. $P$. torreyi grows in more protected low intertidal to subtidal zones and is almost exclusively subtidal in Oregon except in large tidepools. P. scouleri and P. serrulatus occur in the low intertidal zone, primarily in areas of heavy surf, with $P$. serrulatus sometimes occurring at slightly higher and more protected areas of the intertidal than P. scouleri (Phillips 1979, Dennis \& Halse 2008, present study). Both $P$. scouleri and P. serrulatus may be found within the low zone of the intertidal at the same site and in many cases appear nearly identical, but can be distinguished by the number of rootlets at rhizome internodes ( 2 groups of 6 to 10 short rootlets in $P$. scouleri; exactly 2 longer rootlets in P. serrulatus), leaf venation (3 veins in $P$. scouleri; 5 to 7 in P. serrulatus) and blade width (1.5 to $4 \mathrm{~mm}$ in P. scouleri; 2 to $8.5 \mathrm{~mm}$ in P. serrulatus) (Dennis \& Halse 2008).

In the present study, we used field surveys to quantify abundances and morphological differences between the 2 congeners $P$. scouleri and $P$. serrulatus, as well as the community of infaunal and epibiotic macroinvertebrates associated with the surfgrasses. Because both surfgrass species occur along the entire coast, where we know that oceanographic conditions can vary dramatically because of gradients in ocean upwelling and productivity (Menge et al. 1997a,b, 2004, Connolly et al. 2001, Freidenburg et al. 2007), we made our collections at 9 sites nested within 3 capes along this ocean upwelling gradient. This type of 
biogeographic sampling allowed us to consider the functional role of congeners as mediated by oceanographic context in the macroinvertebrate community. Specifically, we asked 3 questions: (1) Do macroinvertebrate communities differ between surfgrass congeners $P$. scouleri and $P$. serrulatus? (2) How does oceanic upwelling modify these communities? (3) What controls the differences in invertebrate community structure between surfgrass species and along an ocean upwelling gradient?

\section{MATERIALS AND METHODS}

We surveyed the distribution and abundance of all 3 surfgrass congeners native to Oregon, as well as the physical structure and associated macroinvertebrate assemblages of Phyllospadix scouleri and P. serrulatus, using censuses and collections from 9 sites among 3 capes on the Oregon coast, spanning over $200 \mathrm{~km}$ (Table 1). Distribution and proportional abundance of all 3 surfgrass species ( $P$. scouleri, $P$. serrulatus and $P$. torreyi) were mapped in July 2010 by walking the entirety of each study site (at all tide heights) and counting the number of patches of each species as they were encountered either on the bench or in tidepools. A patch was defined as an area of surfgrass with distinct edges, thus separated from other patches, but patch area was highly variable (approx. $100 \mathrm{~cm}^{2}$ to $1 \mathrm{~m}^{2}$ ). It was impractical to measure the size of the patches for this study given the large number. However, this method allowed us to calculate the relative proportion of each surfgrass species at each site.
A maximum of 5 samples of surfgrass and associated macroinvertebrate species and sediment were collected at each site during 8 'minus tide' series over a $1 \mathrm{yr}$ period, with monthly collections in summer months (24-30 April 2009, 22-27 June 2009, 2025 July 2009, 18-22 August 2009, 17-22 September 2009) and bi-monthly collections in alternate months in the winter (30 November-2 December 2009, 2831 January 2010 and 26 March-1 April 2010). Samples were selected haphazardly, with an inter-sample distance of 3 to $10 \mathrm{~m}$, from surfgrass beds at a tidal height of ca. $0 \mathrm{~m}$ mean lower low water at the most waveexposed area that was feasibly accessible. For each collection, we removed $100 \mathrm{~cm}^{2}$ square plots of a single surfgrass species, keeping all rhizomes, blades, accreted sediment and macroinvertebrates between the rocky substrate and blade tips within each sample plot intact. Each sample was placed into an individual quart-sized plastic bag in the field, and then stored at $-20^{\circ} \mathrm{C}$ prior to processing. Six samples are missing from the data set: hazardous conditions prevented collection of any of the 5 planned September 2009 Rocky Point samples, and one July 2009 Yachats Beach sample was omitted because of collection technique error. A total of 354 sample plots were collected over the duration of this study.

To determine macroinvertebrate community composition, surfgrass morphology and accreted sediment, we processed samples individually in the laboratory. Each plot was rinsed into nested stainless steel sieves with mesh sizes $63 \mu \mathrm{m}, 125 \mu \mathrm{m}, 710 \mu \mathrm{m}$ and $2 \mathrm{~mm}$. Sediment was loosened from rhizomes with a continuous flow of tap water and manual agitation. Macroscopic

Table 1. Proportion $( \pm \mathrm{SE})$ and statistics (ANOVA, Fisher's F-protected LSD) of 3 surfgrass congeners (Phyllospadix scouleri, P. serrulatus and P. torreyi) at 3 sites nested within 3 Oregon capes (Cape Foulweather [CF], Cape Perpetua [CP], Cape Blanco [CB]) measured in July 2010

\begin{tabular}{|c|c|c|c|c|c|}
\hline Cape & Site & Location & P. scouleri & P. serrulatus & P. torreyi \\
\hline \multirow[t]{4}{*}{ Foulweather } & Fogarty Creek & $44^{\circ} 50^{\prime} 14.68^{\prime \prime} \mathrm{N}, 124^{\circ} 3^{\prime} 29.94^{\prime \prime} \mathrm{W}$ & 0.85 & 0 & 0.15 \\
\hline & Boiler Bay & $44^{\circ} 49^{\prime} 52.75^{\prime \prime} \mathrm{N}, 124^{\circ} 3^{\prime} 37.20^{\prime \prime} \mathrm{W}$ & 0.71 & 0 & 0.29 \\
\hline & Manipulation Bay & $44^{\circ} 49^{\prime} 45.87^{\prime \prime} \mathrm{N}, 124^{\circ} 3^{\prime} 44.38^{\prime \prime} \mathrm{W}$ & 0.62 & 0.13 & 0.25 \\
\hline & Overall \pm SE & & $0.73 \pm 0.07$ & $0.04 \pm 0.04$ & $0.23 \pm 0.04$ \\
\hline \multirow[t]{4}{*}{ Perpetua } & Yachats Beach & $44^{\circ} 19^{\prime} 6.82^{\prime \prime} \mathrm{N}, 124^{\circ} 6^{\prime} 31.94^{\prime \prime} \mathrm{W}$ & 0.40 & 0.50 & 0.10 \\
\hline & Strawberry Hill & $44^{\circ} 14^{\prime} 59.80^{\prime \prime} \mathrm{N}, 124^{\circ} 6^{\prime} 54.09^{\prime \prime} \mathrm{W}$ & 0.41 & 0.53 & 0.06 \\
\hline & Tokatee Kloochman & $44^{\circ} 12^{\prime} 23.13^{\prime \prime} \mathrm{N}, 124^{\circ} 6^{\prime} 59.82^{\prime \prime} \mathrm{W}$ & 0.41 & 0.57 & 0.03 \\
\hline & Overall \pm SE & & $0.41 \pm 0.00$ & $0.53 \pm 0.02$ & $0.06 \pm 0.02$ \\
\hline \multirow[t]{4}{*}{ Blanco } & Cape Blanco North & $42^{\circ} 50^{\prime} 24.41^{\prime \prime} \mathrm{N}, 124^{\circ} 33^{\prime} 52.15^{\prime \prime} \mathrm{W}$ & 0.69 & 0.31 & 0 \\
\hline & Port Orford Head & $42^{\circ} 44^{\prime} 23.23^{\prime \prime} \mathrm{N}, 124^{\circ} 30^{\prime} 49.17^{\prime \prime} \mathrm{W}$ & 1.00 & 0 & 0 \\
\hline & Rocky Point & $42^{\circ} 43^{\prime} 10.36^{\prime \prime} \mathrm{N}, 124^{\circ} 28^{\prime} 0.80^{\prime \prime} \mathrm{W}$ & 1.00 & 0 & 0 \\
\hline & Overall \pm SE & & $0.80 \pm 0.12$ & $0.20 \pm 0.12$ & 0 \\
\hline \multicolumn{6}{|l|}{ Statistics } \\
\hline$F$ & & & 4.9 & 7.0 & 25.4 \\
\hline $\mathrm{p}$ & & & 0.05 & 0.02 & 0.0006 \\
\hline Post hoc & & & $\mathrm{CB}=\mathrm{CF}>\mathrm{CP}$ & $\mathrm{CP}>\mathrm{CB}=\mathrm{CF}$ & $\mathrm{CF}>\mathrm{CP}=\mathrm{CB}$ \\
\hline
\end{tabular}


invertebrates were removed from the blades and among the rhizomes and placed into $70 \%$ ethanol for storage. All macroinvertebrates were counted and identified to the lowest practical taxonomic group (including species, genus and family). Of the 354 samples collected, 352 macroinvertebrate samples were counted and identified; 2 samples were rendered uncountable because of errors in preservation that resulted in their decomposition. Sediment trapped on size-class sieves between $63 \mu \mathrm{m}$ and $2 \mathrm{~mm}$, the geological grain size range for 'sand', was combined, dried to constant mass at $70^{\circ} \mathrm{C}$ (ca. $48 \mathrm{~h}$ ) and then weighed. For each plot, we recorded tiller density and tiller height (mean length in $\mathrm{cm}$ of the 2 longest blades). Aboveground and belowground biomass were determined by separating tillers from rhizomes and drying to constant mass at $70^{\circ} \mathrm{C}$ (ca. $48 \mathrm{~h}$ ) and then weighing. $P$. scouleri and P. serrulatus blade widths, sampled in August 2010 by collecting 30 blades of each species (10 blades from each of 3 haphazardly selected, discontinuous patches) from sites on Cape Foulweather and Cape Perpetua, were measured just above the sheath.

We used 2-factor fixed effects ANOVA to investigate the effect of surfgrass species, cape and their possible interactions on the following response variables: the relative proportion of each surfgrass species, the total macroinvertebrates living in surfgrass (abundance and taxon richness), the 4 most abundant macroinvertebrate groups (together representing ca. $78 \%$ of total abundance) (data were $\log [x+1]$-transformed for analysis but plotted using untransformed data), the morphology of each surfgrass species (tiller density, tiller length, aboveground biomass and belowground biomass) and sediment accretion around surfgrass rhizomes. Fisher's F-protected least significant difference (LSD) tests were conducted on significant factors, unless interactions were found, in which case 1-factor ANOVAs and Fisher's F-protected LSD comparisons were conducted between levels of each factor (Underwood 1997).

Finally, we performed an analysis on the macroinvertebrate functional groups found within the 2 surfgrass species. Taxa were categorized by the following characteristics: habitat usage (infauna vs. epifauna), feeding strategy (deposit feeder, suspension feeder, scavenger, predator and grazer) and diet (herbivore, omnivore and carnivore). To simplify the statistics, we compared the proportion of organisms within each category for each kind of functional group between the 2 surfgrass species (but not each cape) using 2sample Student's $t$-tests. We initially conducted a series of $F$-tests and then used the appropriate $t$-test depending on whether variances were equal or unequal.

\section{RESULTS}

\section{Distribution and proportion of surfgrasses among capes}

Distribution and proportion of the 3 surfgrass congeners varied with species and cape (species $\times$ cape $F_{4,21}=9.8, \mathrm{p}<0.0001$; Table 1). Phyllospadix scouleri was most common at Capes Foulweather and Blanco (between which abundances of this species did not differ) and least common at Cape Perpetua (Table 1). $P$. serrulatus was most common at Cape Perpetua, then Cape Blanco, and least common at Cape Foulweather (Table 1). Finally, P. torreyi was most common at Cape Foulweather compared with Cape Perpetua; none was found at Cape Blanco (Table 1).
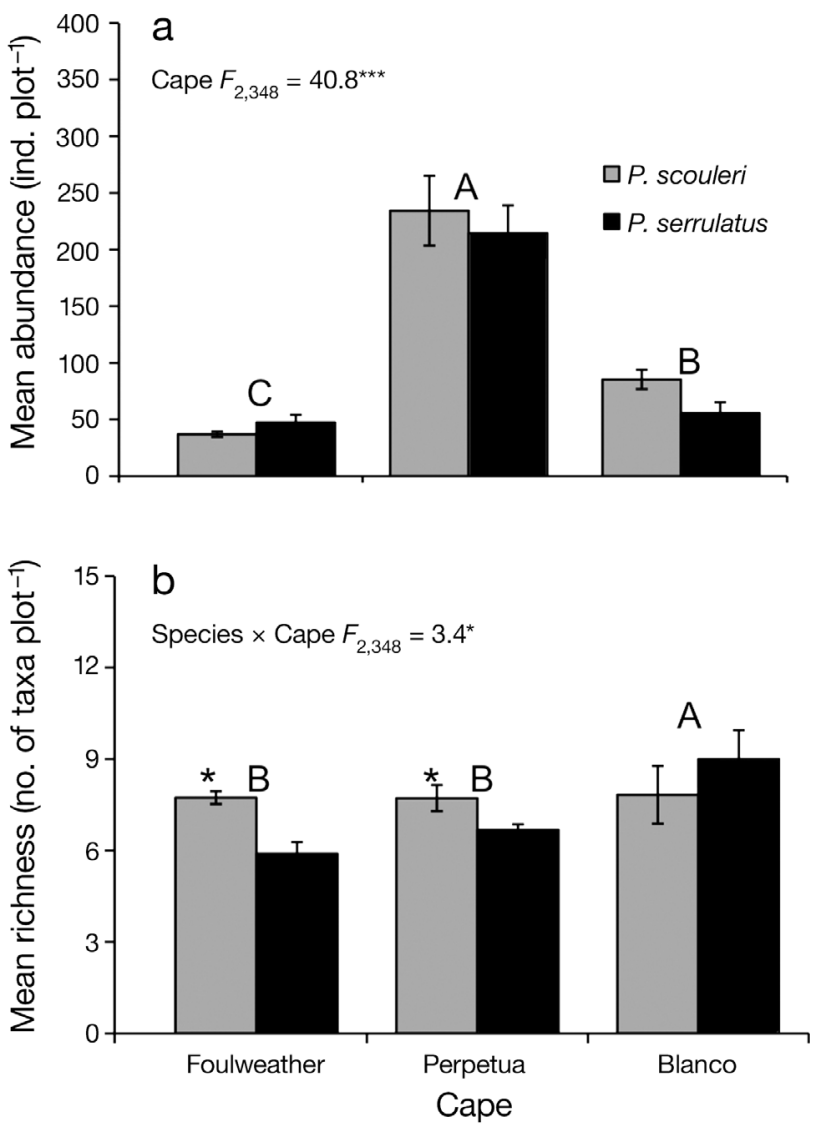

Fig. 1. Means $( \pm \mathrm{SE})$ and statistics (2-way ANOVAs; ${ }^{*} \mathrm{p}<0.05$, ${ }^{* *} \mathrm{p}<0.001,{ }^{* * *} \mathrm{p}<0.0001$ ) for (a) abundance and (b) taxon richness of macroinvertebrates inhabiting 2 surfgrass species (Phyllospadix scouleri and P. serrulatus) across 3 Oregon capes (Foulweather, Perpetua and Blanco). Significant post hoc tests (Fisher's F-protected LSD, p < 0.05) are differentiated by capital letters for capes and by asterisks for surfgrass species. Reported statistics are based on $\log (x+1)$-transformed abundance data, and plots are based on untransformed data. Sample sizes are as follows: Foulweather, P. scouleri n $=101$, $P$. serrulatus $\mathrm{n}=19$; Perpetua, $P$. scouleri $\mathrm{n}=39$, $P$. serrulatus $\mathrm{n}=80 ;$ Blanco, $P$. scouleri $\mathrm{n}=110, P$. serrulatus $\mathrm{n}=5$ 


\section{Macroinvertebrate community structure between surfgrass congeners and among capes}

The abundance of macroinvertebrates differed dramatically by cape but not between the 2 surfgrass species, and the effect of cape did not vary by species (Fig. 1a). Macroinvertebrates were 2.5 to 3.0 times more abundant at Cape Perpetua than at either Cape Blanco or Cape Foulweather, but did not differ between the latter 2 capes (Fig. 1a). Macroinvertebrate taxon richness was context dependent, varying by species and cape (Fig. 1b). By surfgrass species, taxon richness in Phyllospadix serrulatus varied by cape, with Cape Blanco having the highest taxon richness compared with the other 2 capes (Fig. 1b). Taxon richness in $P$. scouleri did not differ among capes, although taxon richness of macroinvertebrates was higher in $P$. scouleri compared with $P$. serrulatus at all capes except Cape Blanco (where there was no between-species difference) (Fig. 1b).

To look more specifically at the differences in taxon composition, we calculated the cumulative abundance of each taxon (36 total). Of the 38481 individual macroinvertebrate specimens collected in the year-long duration of this survey, approximately $78 \%$ of individuals fell into 4 taxonomic groups: the isopod Idotea wosnesenskii Brandt (16135 individuals, ca. $40 \%$ of total), the orbinid polychaete Naineris dendritica Kinberg (species formerly included with N. laevigata) (7020 individuals, ca. $17 \%$ of total), gammaridean amphipods (6115 individuals, ca. $15 \%$ of total) and the mussel Mytilus spp. (2442 individuals, ca. $6 \%$ of total) (Table 2). Because of their overwhelming dominance, these species were the focus of subsequent analyses.

The 4 most abundant macroinvertebrate taxa exhibited different abundance patterns depending on surfgrass species and cape during the 1 yr observational study. All 4 taxa varied by both cape and surfgrass species and there were no interactions (Fig. 2). The abundance of the isopod Idotea wosnesenskii, a motile epifaunal scavenging omnivore, was highest at Cape Perpetua, and was slightly higher at Cape Blanco than at Cape Foulweather (Fig. 2a). I. wosnesenskii were more abundant within Phyllospadix scouleri than within P. serrulatus (Fig. 2a). Abundance of the orbinid polychaete Naineris dendritica, a motile infaunal deposit-feeding herbivore, was higher at Cape Perpetua than at the other sampled capes, which did not differ
Table 2. Cumulative abundance of each observed macroinvertebrate taxon collected within each surfgrass species, Phyllospadix scouleri and P. serrulatus

\begin{tabular}{|c|c|c|c|}
\hline $\begin{array}{l}\text { Macroinvertebrate } \\
\text { taxon }\end{array}$ & $\begin{array}{l}\text { umulative } \\
\text { bundance }\end{array}$ & $\begin{array}{l}\text { Abundance } \\
\text { in P. scouleri }\end{array}$ & $\begin{array}{l}\text { Abundance } \\
\text { in P. serrulatus }\end{array}$ \\
\hline Idotea wosnesenskii & 16135 & 6455 & 9680 \\
\hline Naineris dendritica & 7020 & 1706 & 5314 \\
\hline Amphipods & 6115 & 4686 & 1429 \\
\hline Mytilus spp. & 2442 & 2386 & 56 \\
\hline Sabellidae & 1753 & 1617 & 136 \\
\hline Nereidae & 1655 & 980 & 675 \\
\hline Idotea stenops & 668 & 423 & 245 \\
\hline Tegula sp. & 469 & 222 & 247 \\
\hline Phascolosoma sp. & 375 & 309 & 66 \\
\hline Nucella sp. & 366 & 177 & 189 \\
\hline Pugettia sp. & 233 & 221 & 12 \\
\hline Petrolisthes sp. & 158 & 151 & 7 \\
\hline Pagurus sp. & 126 & 67 & 59 \\
\hline Anemones & 122 & 60 & 62 \\
\hline Nereis brandti & 120 & 102 & 18 \\
\hline Balanus sp. & 116 & 107 & 9 \\
\hline Oedignathus sp. & 114 & 114 & 0 \\
\hline Halosydna sp. & 104 & 84 & 20 \\
\hline Idotea montereyensis & 71 & 48 & 23 \\
\hline Gnorimosphaeroma sp. & 63 & 61 & 2 \\
\hline Unknown sea cucumber & 45 & 8 & 37 \\
\hline Hemigrapsus sp. & 36 & 35 & 1 \\
\hline Limpets & 36 & 16 & 20 \\
\hline Lumbrineridae & 33 & 27 & 6 \\
\hline Clams & 31 & 29 & 2 \\
\hline Pollicipes sp. & 24 & 12 & 12 \\
\hline Leptasterias pusilla & 15 & 15 & 0 \\
\hline Nemertea & 14 & 12 & 2 \\
\hline Unknown brittlestar & 10 & 10 & 0 \\
\hline Mopalia sp. & 4 & 4 & 0 \\
\hline Pisaster ocraceus & 2 & 2 & 0 \\
\hline Apodichthys flavidus & 2 & 2 & 0 \\
\hline Cancersp. & 1 & 1 & 0 \\
\hline Styela montereyensis & 1 & 1 & 0 \\
\hline Cottidae & 1 & 1 & 0 \\
\hline Strongylocentrotus purpuratu. & us & 1 & 0 \\
\hline Total abundance 3 & 38481 & 20152 & 18329 \\
\hline
\end{tabular}

from each other (Fig. 2b). N. dendritica were far more abundant in P. serrulatus than in P. scouleri (Fig. 2b). Abundance of gammaridean amphipods, motile epifaunal grazing herbivores, was higher at Cape Perpetua than at the other sampled capes, which did not differ from each other (Fig. 2c). Amphipods were more abundant within P. scouleri than within P. serrulatus (Fig. 2c). Raw abundance of juvenile $(<2 \mathrm{~cm})$ Mytilus spp., sessile epifaunal suspension-feeding omnivores, was highest at Cape Perpetua, but this pattern is attributable to one late-summer spike in recruitment at sites in that region. Using log-transformed data, Mytilus spp. abundance was highest at Cape Blanco (Fig. 2d) and greater in $P$. scouleri than in P. serrulatus (Fig. 2d). 

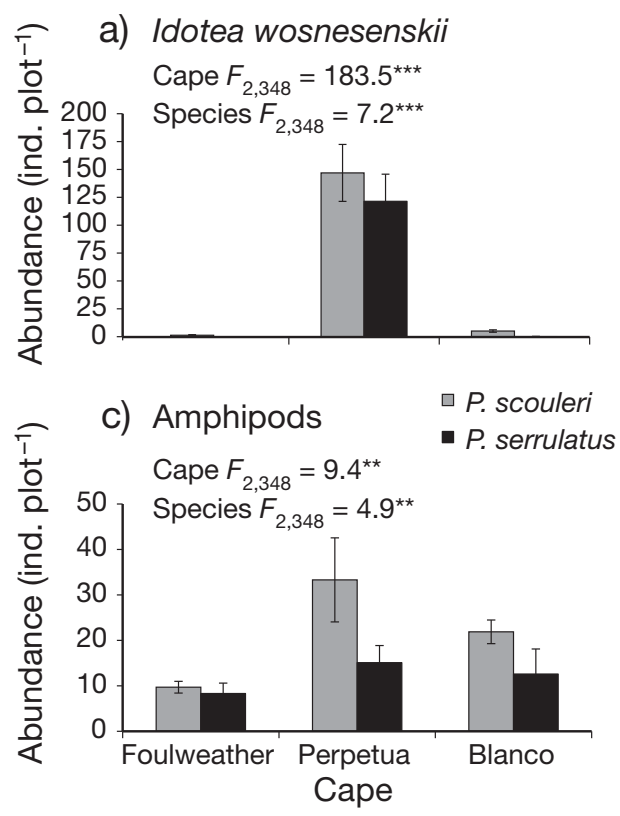
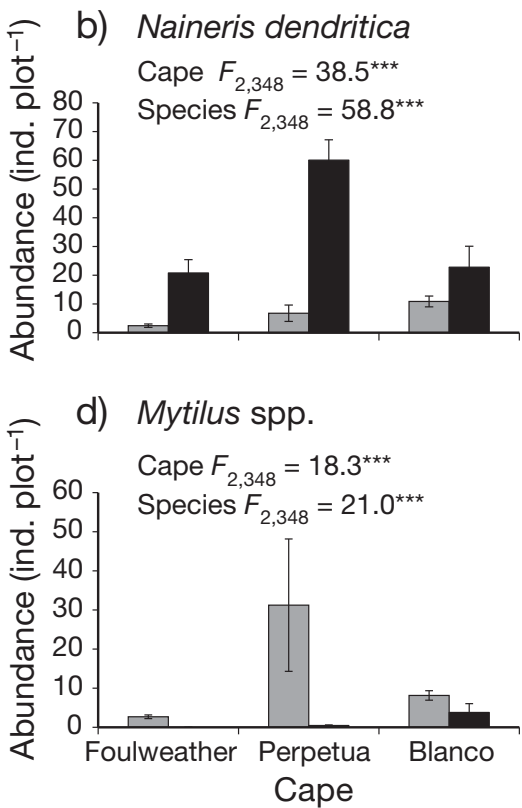

Fig. 2. Means $( \pm \mathrm{SE})$ and statistics (2-way ANOVAs; ${ }^{*} p<0.05$, $\left.{ }^{* *} \mathrm{p}<0.001,{ }^{* * *} \mathrm{p}<0.0001\right)$ for abundance of the 4 most common macroinvertebrate taxa collected from Phyllospadix scouleri and $P$. serrulatus at Capes Foulweather, Perpetua and Blanco: (a) Idotea wosnesenskii, (b) Naineris dendritica, (c) amphipods and (d) Mytilus spp. Sample sizes are the same as in Fig. 1

\section{Macroinvertebrate functional group differences between surfgrass congeners}

The habitat usage by macroinvertebrates varied between the surfgrass species (Fig. 3a). There were proportionally more epifauna within Phyllospadix scouleri than within $P$. serrulatus (equal variance, $t=$ 2.6 , df $=350, p=0.01$ ) and the opposite was true for infauna. The feeding strategies of macroinvertebrates also varied between surfgrass species (Fig. 3b). There were proportionally more suspension feeders (animals that feed by straining suspended particles from water) (unequal variance, $t=12.3, \mathrm{df}=334, \mathrm{p}<0.0001$ ) and grazers (animals that feed by ingesting plants and other multicellular autotrophs) (unequal variance, $t=$ 8.6, df $=278, \mathrm{p}<0.0001$ ) within $P$. scouleri and proportionally more deposit feeders (animals that feed on detritus that collects on or in benthos) (unequal variance, $t=-7.1$, $\mathrm{df}=154, \mathrm{p}<0.0001$ ), scavengers (animals that consume animal tissue not eaten by a predator) (unequal variance, $t=-3.9, \mathrm{df}=153, \mathrm{p}<0.0001)$ and predators (animals that feed on organisms that they attack and usually kill) (unequal variance, $t=-1.9$, df $=119$, $\mathrm{p}=0.03$ ) within $P$. serrulatus. Finally, the diet types among macroinvertebrates varied between surfgrass species in some cases (Fig. 3c). There were proportionally more omnivores (animals that consume both plants and animals as primary food source) in $P$. scouleri (equal variance, $t=3.3, \mathrm{df}=$ $350, \mathrm{p}=0.001$ ), more herbivores (animals that consume plant or algal tissue) in $P$. serrulatus (equal variance, $t=$ $-2.4, \mathrm{df}=350, \mathrm{p}=0.02$ ) and statistically the same proportion of carnivores (animals that consume animal tissue) in both habitats (unequal variance, $t=$ -1.8 , df $=140, p=0.07$ ).
Fig. 3. Mean proportional abundances of macroinvertebrates categorized by ecological functional groups for the 2 surfgrass species Phyllospadix scouleri and P. serrulatus. Groupings are (a) habitat usage, (b) feeding strategy and (c) diet. Total number of samples was $352(P$. scouleri $\mathrm{n}=248$, $P$. serrulatus $\mathrm{n}=104$ ) 


\section{Surfgrass morphology between congeners and among capes}

We found that many surfgrass morphological features and associated accreted sediment varied by surfgrass species and cape (Fig. 4). Phyllospadix scouleri and $P$. serrulatus differed either as main effects or through interactions with cape in several measures: tiller density, tiller length, tiller biomass and rhizome biomass (Fig. 4). In all cases, $P$. scouleri had higher values compared with $P$. serrulatus at all capes, except for tiller density and rhizome biomass, which did not differ between the 2 species at Cape Blanco only (Fig. 4a,c). In addition, for $P$. serrulatus, tiller density and rhizome biomass were higher at Cape Blanco compared with the other 2 capes (Fig. 4a,d). Morphological measures of $P$. scouleri did not differ among capes. Moreover, the sediment accreted by surfgrass rhizomes varied by species and cape (Fig. 4e). P. serrulatus had roughly 2.3 times more sediment than P. scouleri (Fig. 4e), but this depended on cape, with Cape Blanco showing no difference in accreted sediment between both species (Fig. 4e). Finally, at Capes Foulweather and Perpetua, $P$. serrulatus blades were wider than $P$. scouleri blades, and this did not vary by cape (Fig. 4f).

\section{DISCUSSION}

Large and complex foundation species commonly create significant amounts of benthic marine habitat (Orth 1977, Witman 1985, Zimmerman et al. 1989). Because of their ubiquity, these foundation species indirectly facilitate the establishment and persistence
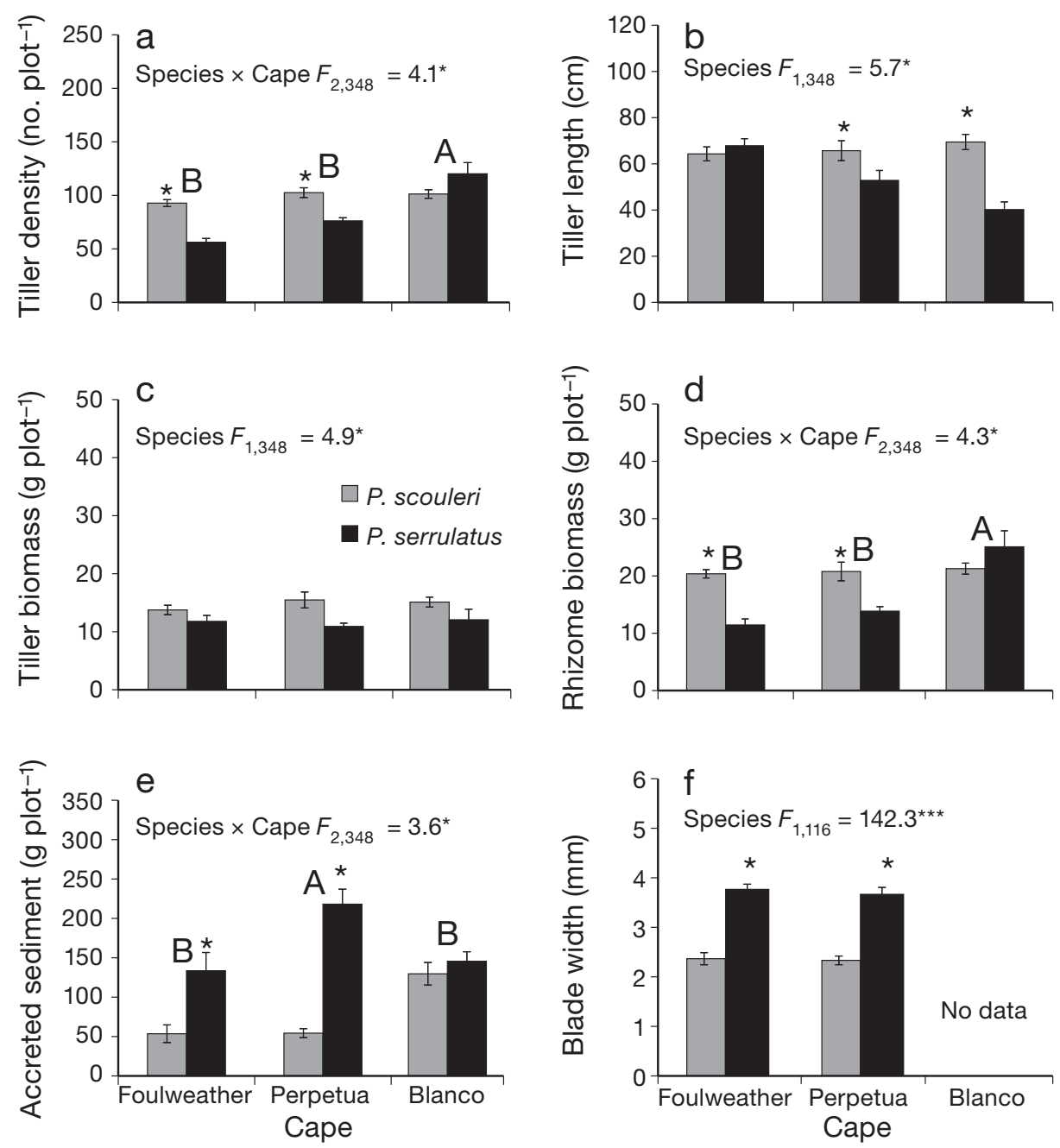

Fig. 4. Means ( \pm SE) and statistics (2-way ANOVAs; $\left.{ }^{*} \mathrm{p}<0.05,{ }^{* *} \mathrm{p}<0.001,{ }^{* * *} \mathrm{p}<0.0001\right)$ for (a) tiller density, (b) tiller length, (c) tiller biomass, (d) rhizome biomass, (e) sediment and (f) tiller widths for different surfgrass species (Phyllospadix scouleri and P. serrulatus) across Oregon capes (Foulweather, Perpetua and Blanco). Significant post hoc tests (Fisher's F-protected LSD, p < 0.05) are differentiated by capital letters for capes and by asterisks for surfgrass species. Sample sizes are the same as in Fig. 1 
of associated resident populations via creation of spatial refuge from environmental stress, protection from predation, enhancement of local propagule supply, entrapment, and retention and supply of food and other necessary resources (Bruno \& Bertness 2001). In the present study, we showed that 2 outwardly similar congeneric surfgrass species, which co-occur at many Oregon sites, varied significantly in terms of their function as habitat for resident species. In particular, we found that resident macroinvertebrate species and functional groups differed between the 2 surfgrass species, Phyllospadix scouleri and P. serrulatus, despite similarities in macroinvertebrate abundance (Figs. 1 to 3 , Table 2). In addition, we discovered that the abundance of macroinvertebrates was 2.5- to 3-fold higher for the same amount of habitat sampled at one particularly productive region along the Oregon coast (Cape Perpetua) (Figs. 1a, $2 \& 4$ ). Thus, our results suggest that this abundant and diverse assemblage of phytal macroinvertebrates is responding to both subtle localscale functional differences between the surfgrass species and regional differences among capes.

\section{Functional differences in the 2 surfgrass congeners}

We explored the functional reasons why these similar foundation species might harbor different species by comparing the macroinvertebrate species and functional groups within these habitats with the morphological differences of the grasses themselves. Two basic patterns were found.

First, Phyllospadix scouleri, which has greater tiller biomass and density (per $100 \mathrm{~cm}^{2}$ ) but thinner blades compared with P. serrulatus (Fig. $4 \mathrm{a}, \mathrm{C}, \mathrm{f}$ ), seems to provide a better habitat for epifaunal species, especially grazing and suspension-feeding species such as amphipods, isopods and juvenile mussels (Fig. 3). Although there was no difference in the numbers of the isopod Idotea wosnesenskii in either habitat (Fig. 2a), there were more amphipods in P. scouleri (Fig. 2c), suggesting that it provided a better habitat in which to cling. Gammaridean amphipods have been shown to be particularly sensitive to habitat architecture, especially algal branch number and width, possibly because of their dorsal-ventral elongated body plan (Hacker \& Steneck 1990). This may be less important for isopods, which are more flattened in the dorsalventral plane and thus potentially could cling to a wider variety of branch widths.

Second, even though the rhizomes of Phyllospadix scouleri were found to have larger biomass per $100 \mathrm{~cm}^{2}$ (in most cases) than P. serrulatus (Fig. 4d), they accreted much less sand than those of their congener (Fig. 4e), suggesting that the amount of intersti- tial space between the rhizomes could be an important functional difference between these surfgrasses, although we did not explicitly quantify this value. Deposit-feeding and scavenging infaunal species (mostly worms) were much more abundant in P. serrulatus than in P. scouleri (Fig. 3b). This is unsurprising, as these species require burrowing substrate and unicellular benthic organisms as food supply. One particularly abundant species, Naineris dendritica, is commonly found in the sediment of sandy beaches (Ricketts et al. 1985) but is also abundant in the rocky intertidal in areas of stabilized sediment (Crouch 1991, present study). Naineris worms are 'conveyorbelt' deposit feeders, in that they rework surrounding sediment, removing particulate organic matter, particularly single-celled dinoflagellates (Giangrande et al. 2002). These worms are effective burrowers (an escape mechanism from unfavorable conditions) with a ciliary system to allow for efficient water circulation inside their burrow (Giangrande \& Petraroli 1991). Although the relatively low rhizome biomass and corresponding thick sediment associated with $P$. serrulatus potentially provides ideal habitat for burrowing worms such as Naineris, P. scouleri rhizomes seem to be a more suitable settling substrate for juvenile Mytilus spp. (Fig. 2d), possibly because of the lack of sediment.

\section{Regional differences in the abundance and richness of phytal macroinvertebrates}

At the local scale, it is clear that morphological differences exist between the 2 surfgrass congeners that provide different kinds of habitat for phytal macroinvertebrates. However, we found that these animals also responded to regional-scale differences, with many more individuals present for a given amount of habitat at Cape Perpetua, a region on the Oregon coast well known for very high phytoplankton and sessile invertebrate production (Menge et al. 1997a,b), than at the 2 other capes (Figs. 1a \& 2). These results, along with the strong differences in oceanography among the capes, suggest that oceanic upwelling and productivity could play an even larger role in structuring of communities associated with surfgrass than we initially anticipated.

Research by Menge and colleagues (Menge et al. 1997a,b, 2004, 2008, 2009, Connolly et al. 2001, Leslie et al. 2005, Barth et al. 2007, Freidenburg et al. 2007, Broitman et al. 2008, Kavanaugh et al. 2009) shows that seasonal oceanic upwelling processes are critical in structuring sessile invertebrate and macrophyte communities along the Pacific coast. Blooms of phytoplankton caused by upwelling of nutrients from depth 
can have several effects on intertidal biota, including direct bottom-up effects on growth of filter-feeding invertebrates, as well as effects on larval development and recruitment (Menge et al. 1997b, 2004, 2008, 2009, Barth et al. 2007, Broitman et al. 2008). Phytoplankton abundance can negatively influence macrophyte communities if fast-growing invertebrates are able to preempt space or if phytoplanktonic blooms attenuate light availability (Menge et al. 1997a, 2004, 2008, Freidenburg et al. 2007, Kavanaugh et al. 2009).

Intensity of upwelling and retention of upwelled water along the west coast of North America varies with both latitude and geographic features (Hickey \& Banas 2003). Major coastal headlands, including Capes Foulweather, Perpetua and Blanco, show strengthened upwelling of nutrient-rich water, as this is where favorable winds become more intense and the southward-flowing California Current is deflected offshore. Cape Foulweather (the most northern cape sampled in this study), just north of Depoe Bay, OR, USA, has a narrow offshore continental shelf (ca. $5 \mathrm{~km}$ ), resulting in relatively efficient offshore shunting of coastal waters, along with phytoplankton and larvae. Thus, sessile invertebrate recruitment and growth is lower than at Cape Perpetua. Cape Perpetua, just south of Yachats, OR, USA, has a broad continental shelf (ca. $15 \mathrm{~km}$ ), producing a gyre of relatively stationary water, which fuels massive blooms of phytoplankton, increased rates of larval development, retention and recruitment, and boosts sessile invertebrate and predator secondary production. Finally, Cape Blanco, near Port Orford, OR, USA, is a major headland in southern Oregon and a boundary between 2 distinct oceanic upwelling regimes along the California Current (Connolly et al. 2001). A separating coastal upwelling current at Cape Blanco (Barth et al. 2000) can result in both high nutrient delivery and high sessile invertebrate recruitment, making it particularly good for both sessile invertebrates and macrophytes (S. D. Hacker \& B. A. Menge unpubl. data).

Our research suggests that this pattern in productivity at the regional or cape level is also reflected in the mobile phytal macroinvertebrate community, irrespective of the species of surfgrass habitat. Abundances of macroinvertebrates were much higher at the most productive region, Cape Perpetua, suggesting that the higher productivity is stimulating higher secondary production in these macroinvertebrates. In addition, even though both Phyllospadix scouleri and P. serrulatus occur in different proportions among the capes (Table 1), together they cover roughly the same amount of area in the low intertidal at the 3 capes (roughly $20 \%$; S. D. Hacker \& B. A. Menge unpubl. data). Thus, habitat limitation is unlikely to be a factor producing higher densities of animals within a given size of Phyllospadix habitat at Cape Perpetua. One factor that did vary among capes was sand accretionCape Perpetua had higher sand accretion than the other 2 capes (Fig. 4e) - and this may have been a factor determining macroinvertebrate abundance, especially for the infauna such as Naineris dendritica (Fig. 2b) but less so for the epifauna.

Taxon richness was not consistent across all capes (Fig. 1b), providing further evidence that regional processes modify the composition of these communities of macroinvertebrate residents. Macroinvertebrates at Capes Foulweather and Perpetua, though vastly different in overall abundance, had the same number and types of taxa (Fig. 1b). Cape Blanco, though, had slightly more species (Fig. 1b). Species seen at Cape Blanco and not at Capes Foulweather or Perpetua were very rare (occurring only once in the data set) and include a juvenile crab from the genus Cancer and a juvenile urchin, Strongylocentrotus purpuratus. In other cases, species occurring at very low abundances at Capes Foulweather or Perpetua were found at higher abundances (and in more samples) at Cape Blanco (e.g. anemones, Petrolisthes spp., Hemigrapsus sp. and Nereis brandti), thus potentially contributing to the overall higher richness found there. Cape Blanco is in an area of biogeographic overlap: a convergence of distinct currents occurs within this region that results in consistently higher species richness when compared with adjacent capes (Sotka et al. 2004).

The 4 most abundant macroinvertebrate taxa, Idotea wosnesenskii, Naineris dendritica, gammaridean amphipods and Mytilus spp., exhibited different patterns in abundance depending on surfgrass species (Fig. 2). Despite different community compositions in association with each surfgrass species (Table 2), the most abundant invertebrates species occurred in relatively high densities at all the capes with the exception of the isopod I. wosnesenskii, which occurred almost exclusively at Cape Perpetua (Fig. 2a). This species seems to be a habitat generalist, occurring in similar numbers in both Phyllospadix scouleri and P. serrulatus. Isopod species from the genus Idotea have strong jaws used in scraping and processing food. These organisms are omnivorous, but commonly feed upon fouling epiphytes via biting or scraping of seaweed or seagrass surfaces (Naylor 1955). Epiphytic microscopic algae may be more common at Cape Perpetua, where planktonic algal blooms are occasionally extremely high (especially in midsummer). These isopods utilize direct development via brooding in reproduction instead of production of pelagic larvae; thus, local retention of juveniles at Cape Perpetua could be a contributing factor in the high abundance of this species at this location. 


\section{Implications of local and regional differences in macroinvertebrate community structure}

Two conclusions follow from the results we report here. First, subtle but significant differences in congeneric foundation species can have important implications for associated resident species. We found that differences in plant morphology (tiller density, blade width and aboveground and belowground biomass) and sediment accretion exist between the 2 surfgrass congeners that change their function as foundation species. If one suggested that the community composition of associated macroinvertebrates in the 2 surfgrass species were the same, then one would underestimate the entire functional group of deposit feeders. The conservation implications of these differences are significant because coastal foundation species contribute to many important ecosystem functions and services (Barbier et al. 2011). As decisions are made regarding shoreline zoning and protection, it will be increasingly important to understand the important similarities and differences in the functions of these foundation species, particularly congeners.

Second, understanding the relative role that larger spatial scale plays in moderating the effects of foundation species is equally important to conservation. In this study, the absolute amount of habitat provided by these 2 foundation species was less important to the abundance, and in some cases the richness, of macroinvertebrate species than were the regional differences likely driven by oceanography and the corresponding productivity of that region. As has been shown previously for algal and invertebrate recruitment and community composition, Cape Perpetua is a major hotspot for macroinvertebrate diversity (Schoch et al. 2006) and abundance (Leslie et al. 2005). The research reported here emphasizes the functional and scale-dependent complexity of the relationship between foundation species and their residents.

Acknowledgements. We thank S. Close, R. Craig, S. Gerrity, J. Henderson, D. Kraft, A. Molin, C. Pennington, M. Poole, M. Prechtl and S. Steingass for invaluable field and laboratory assistance. We also thank S. Close, S. Gregory, S. Henkel, M. Hessing-Lewis, A. Iles, B. Menge, J. Rose and P. Zarnetske for comments and edits on earlier versions of the paper. We appreciate the helpful comments of 3 anonymous reviewers and the editor. This work is based on a thesis submitted in partial fulfillment of requirements for the Master of Science in Zoology at Oregon State University (O.M.M.). It was supported by OSU's Department of Zoology funds to S.D.H. and O.M.M. We especially thank B. Menge and OSU's Partnership for Interdisciplinary Studies of Coastal Oceans (PISCO) for partial summer support to O.M.M. This is contribution 395 from PISCO, funded primarily by the Gordon and Betty Moore Foundation and David and Lucile Packard Foundation.

\section{LITERATURE CITED}

Bando KJ (2006) The roles of competition and disturbance in a marine invasion. Biol Invasions 8:755-763

Barbier EB, Hacker SD, Kennedy C, Koch, EW, Stier AC, Silliman BR (2011) The value of estuarine and coastal ecosystem services. Ecol Monogr 81:169-193

Barth JA, Pierce SD, Smith RL (2000) A separating coastal upwelling jet at Cape Blanco, Oregon and its connection to the California Current System. Deep-Sea Res II 47: 783-810

Barth JA, Menge BA, Lubchenco J, Chan F and others (2007) Delayed upwelling alters nearshore coastal ocean ecosystems in the northern California current. Proc Natl Acad Sci USA 104:3719-3724

Bertness MD, Callaway R (1994) Positive interactions in communities. Trends Ecol Evol 9:191-193

Bertness MD, Hacker SD (1994) Physical stress and positive associations among marsh plants. Am Nat 144:363-372

Bertness MD, Leonard GH, Levine JM, Schmidt PR, Ingraham AO (1999) Testing the relative contribution of positive and negative interactions in rocky intertidal communities. Ecology 80:2711-2726

Broitman BR, Blanchette CA, Menge BA, Lubchenco J and others (2008) Spatial and temporal variability in the recruitment of intertidal invertebrates along the west coast of the USA. Ecol Monogr 78:403-421

Bruno JF, Bertness MD (2001) Habitat modification and facilitation in benthic marine communities. In: Bertness MD, Hay ME, Gaines SD (eds) Marine community ecology. Sinauer, Sunderland, MA, USA

Bruno JF, Stachowicz JJ, Bertness MD (2003) Inclusion of facilitation into ecological theory. Trends Ecol Evol 18: 119-125

Connolly SR, Menge BA, Roughgarden J (2001) A latitudinal gradient in recruitment of intertidal invertebrates in the northeast Pacific Ocean. Ecology 82:1799-1813

Crouch CA (1991) Infaunal polychaetes of a rocky intertidal surfgrass bed in southern California. Bull Mar Sci 48: 386-394

> Dayton PK (1971) Competition, disturbance and community organization: the provision and subsequent utilization of space in a rocky intertidal community. Ecol Monogr 41: 351-389

Dennis LJ, Halse RR (2008) Aquatic and wetland plants of Oregon. Unical Press, Aloha, OR

Ellison AM, Bank MS, Clinton BD, Colburn EA and others (2005) Loss of foundation species: consequences for the structure and dynamics of forested ecosystems. Front Ecol Environ 3:479-486

Fishlyn DA, Phillips DW (1980) Chemical camouflaging and behavioral defenses against a predatory seastar by three species of gastropods from the surfgrass Phyllospadix community. Biol Bull 158:34-48

- Freidenburg TL, Menge BA, Halpin PM, Webster M, SuttonGrier A (2007) Cross-scale variation in top-down and bottom-up control of algal abundance. J Exp Mar Biol Ecol $347: 8-29$

Giangrande A, Petraroli A (1991) Reproduction, larval development and post-larval growth of Naineris laevigata (Polychaeta, Orbiniidae) in the Mediterranean Sea. Mar Biol 111:129-137

> Giangrande A, Montresor M, Cavallo A, Licciano M (2002) Influence of Naineris laevigata (Polychaeta: Orbiniidae) on vertical grain size distribution, and dinoflagellate resting stages in the sediment. J Sea Res 47:97-108

Gibbs RE (1902) Phyllospadix as a beach-builder. Am Nat 36: 
101-109

Hacker SD, Dethier MN (2006) Community modification by a grass invader has differing impacts for marine habitats. Oikos 113:279-286

Hacker SD, Dethier MN (2009) Differing consequences of removing ecosystem-modifying invaders: significance of impact and community context to restoration potential. In: Rilov G, Crooks JA (eds) Biological invasions in marine ecosystems. Ecological Studies 204. Springer-Verlag, Berlin, p. 375-385

Hacker SD, Gaines SD (1997) Some implications of direct positive interactions for community species diversity. Ecology 78:1990-2003

> Hacker SD, Steneck RS (1990) Habitat architecture and the abundance and body-size-dependent habitat selection of a phytal amphipod. Ecology 71:2269-2285

Hacker SD, Zarnetske P, Seabloom E, Ruggiero P, Mull J, Gerrity S, Jones C (2011) Subtle differences in two nonnative congeneric beach grasses significantly affect their colonization, spread, and impact. Oikos 120 (in press) doi: 10.1111/j.1600-0706.2011.18887.x

Hahn DR (2003) Alteration of microbial community composition and changes in decomposition associated with an invasive intertidal macrophyte. Biol Invasions 5:45-51

> Hay ME, Parker JD, Burkepile DE, Caudill CC, Wilson AE, Hallinan ZP, Chequer AD (2004) Mutualisms and aquatic community structure: the enemy of my enemy is my friend. Annu Rev Evol Syst 35:175-197

Hemminga MA, Duarte CM (2000) Seagrass ecology. Cambridge University Press, New York, NY

- Hickey BM, Banas NS (2003) Oceanography of the US Pacific Northwest coastal ocean and estuaries with application to coastal ecology. Estuaries 26:1010-1031

> Jenkins GP, Sutherland CR (1997) The influence of habitat structure on nearshore fish assemblages in a southern Australian embayment: colonisation and turnover rate of fishes associated with artificial macrophyte beds of varying physical structure. J Exp Mar Biol Ecol 218:103-125

> Jones CG, Lawton JH, Shachak M (1994) Organisms as ecosystem engineers. Oikos 69:373-386

Kavanaugh MT, Nielsen KJ, Chan FT, Menge BA, Letlier RM, Goodrich LM (2009) Experimental assessment of the effects of shade on an intertidal kelp: Do phytoplankton blooms inhibit growth of open-coast macroalgae? Limnol Oceanogr 54:276-288

> Larned ST (2003) Effects of the invasive, nonindigenous seagrass Zostera japonica on nutrient fluxes between the water column and benthos in a NE Pacific estuary. Mar Ecol Prog Ser 254:69-80

Leslie HM, Breck EN, Chan F, Lubchenco J, Menge BA (2005) Barnacle reproductive hotspots linked to nearshore ocean conditions. Proc Natl Acad Sci USA 102: 10534-10539

> Menge BA, Daley BA, Wheeler PA, Strub PT (1997a) Rocky intertidal oceanography: an association between community structure and nearshore phytoplankton concentration. Limnol Oceanogr 42:57-66

Menge BA, Daley BA, Wheeler PA, Dahlhoff E, Sanford E, Strub PT (1997b) Benthic-pelagic links and rocky intertidal communities: Bottom-up effects on top-down control? Proc Natl Acad Sci USA 94:14530-14535

> Menge BA, Blanchette CA, Raimondi P, Freidenburg TL and others (2004) Species interaction strength: testing model predictions along an upwelling gradient. Ecol Monogr 74: 663-684

> Menge BA, Allison GW, Blanchette CA, Farrell TM, Olson

Editorial responsibility: Kenneth Heck Jr.,

Dauphin Island, Alabama, USA
AM, Turner TA, van Tamelen P (2005) Stasis or kinesis? Hidden dynamics of a rocky intertidal macrophyte mosaic revealed by a spatially explicit approach. J Exp Mar Biol Ecol 314:3-39

Menge BA, Chan F, Lubchenco J (2008) Response of a community dominant to climate patterns in rocky intertidal ecosystems. Ecol Lett 11:151-162

Menge BA, Chan F, Nielsen KJ, DiLorenzo E, Lubchenco J (2009) Climatic variation alters supply-side ecology: impact of climate patterns on mussel recruitment. Ecol Monogr 79:379-395

Naylor E (1955) The diet and feeding mechanism of Idotea. J Mar Biol Assoc UK 34:347-355

Orth RJ (1977) The importance of sediment stability in seagrass communities. In: Coull BC (ed) Ecology of marine benthos. University of South Carolina Press, Columbia, SC

Phillips RC (1979) Ecological notes on Phyllospadix (Potamogetonaceae) in the Northeast Pacific. Aquat Bot 6:159-170

Posey MH (1988) Community changes associated with the spread of an introduced seagrass, Zostera japonica. Ecology 69:974-983

Power ME, Tilman D, Estes JA, Menge BA and others (1996) Challenges in the quest for keystones. BioScience 46: 609-620

Ricketts EF, Calvin J, Hedgpeth JW (1985) Between Pacific tides, 5th edn. Stanford University Press, Stanford, CA

Ruesink JL, Hong JS, Wisehart L, Hacker SD, Dumbauld BR, Hessing-Lewis M, Trimble AC (2010) Congener comparison of native (Zostera marina) and introduced ( $Z$. japonica) eelgrass at multiple scales within a Pacific Northwest estuary. Biol Invasions 12:1773-1789

Schoch GC, Menge BA, Allison G, Kavanaugh M, Thompson SA, Wood SA (2006) Fifteen degrees of separation: latitudinal gradients of rocky intertidal biota along the California current. Limnol Oceanogr 51:2564-2585

Sotka EE, Wares JP, Barth JA, Grosberg RK, Palumbi SR (2004) Strong genetic clines and geographical variation in gene flow in the rocky intertidal barnacle Balanus glandula. Mol Ecol 13:2143-2156

Stachowicz JJ (2001) Mutualism, facilitation, and the structure of ecological communities. BioScience 51:235-246

Stewart JG, Myers B (1980) Assemblages of algae and invertebrates in Southern California Phyllospadix-dominated intertidal habitats. Aquat Biol 9:73-94

> Trowbridge CD (1995) Establishment of the green alga Codium fragile ssp. tomentosoides on New Zealand rocky shores: current distribution and invertebrate grazers. J Ecol 83:949-965

Turner T (1985) Stability of rocky intertidal surfgrass beds: persistence, preemption, and recovery. Ecology 66:83-92

Turner T, Lucas J (1985) Differences and similarities in the community roles of intertidal surfgrasses. J Exp Mar Biol Ecol 89:175-189

Underwood JA (1997) Experiments in ecology: their logical design and interpretation using analysis of variance. Cambridge University Press, Cambridge

- Webster PJ, Rowden AA, Attrill MJ (1998) Effect of shoot density on the infauna macroinvertebrate community within a Zostera marina seagrass bed. Estuar Coast Shelf Sci 47: 351-357

> Witman JD (1985) Refuges, biological disturbance, and rocky subtidal community structure in New England. Ecol Monogr 55:421-445

Zimmerman RT, Minello T, Baumer T, Castiglione M (1989) Oyster reef as habitat for estuarine macrofauna. NOAA Tech Memo NMFS-SEFC-249. NOAA, Silver Spring, MD 